\title{
Effects of Institutional Quality on FDI in Provinces of Vietnam: \\ Empirical Evidence Based on Differenced Panel GMM
}

\author{
NGUYEN VAN BON \\ University of Economics HCMC - bonvnguyen@yahoo.com
}

\begin{abstract}
ARTICLE INFO
ABSTRACT

Article history:

Received:

Dec. 162014

Received in revised form:

Mar. 32015

Accepted:

Jun. 282015

Keywords:

institutional quality, foreign direct investment (FDI), differenced panel

Foreign direct investment (FDI) has been strongly affecting the world economy during the past years and is a critical topic for both developing and developed countries. Most countries, particularly developing ones, always attempt to adjust and modify appropriate policies and institutions to attract FDI inflows. In the context of Vietnam, does the institutional quality have any effect on attracting FDI inflows in provinces? To answer clearly and exactly this question, the impact of institutional quality on attracting FDI inflows is empirically investigated in a sample of 43 provinces of Vietnam over the period of 2005-2012 via the estimation technique of difference panel GMM. Estimated results indicate that in the total sample of all provinces the institutional quality has significantly positive effects on the FDI flows. However, in the sub-sample of provinces the impact of the institutional quality on attracting FDI inflows in Northern and Southern regions are statistically significant while that in Central region is not.
\end{abstract} GMM, provinces of Vietnam. 


\section{Introduction}

The FDI capital has been strongly affecting the world economy during the past years and is a critical topic for both developing and developed countries. FDI is a fixed form of investment in international business activities carried out by multinational companies. The positive impact of FDI inflows in host countries is expected via capital accumulation, technical transfer, imitation of know-how, innovation, and then economic growth. Thus, most countries, especially developing ones, always attempt to adjust and modify appropriate policies and institutions to attract FDI inflows.

According to Dang (2013), foreign investors may affect economic activities and institutions of local governments by some mechanisms. First, foreign investors can provide local policy-makers with more information on laws and regulations in other countries in which foreign enterprises operate. Second, foreign investors may force local leaders to reform by threatening to leave for more favorable investment environments, taking away the province of employment and tax revenue. Third, higher FDI flows may make local governments more autonomously carry out experiments with policy reforms. In addition, due to a positive relationship between foreign direct investment and business environment, domestic private sector would also be expected to gain benefits from provincial governance reforms and improved public services. Thus, these arguments imply that institutional quality has strong impact on attracting FDI inflows, and conversely, FDI inflows play an important role to promote introduction of good institutions.

However, in the context of Vietnam, does the institutional quality have any effect on attracting FDI inflows in provinces? To answer clearly and exactly this question, the impact of institutional quality on attracting FDI inflows is empirically investigated with control variables of real GDP per capita, labor force, development gap, trade openness, and infrastructure in a sample of 43 provinces of Vietnam, namely Long An, Tien Giang, Ben Tre, Vinh Long, An Giang, Kien Giang, Can Tho, Binh Phuoc, Tay Ninh, Binh Duong, Dong Nai, Ba Ria - Vung Tau, Ho Chi Minh City, Ha Noi, Vinh Phuc, Bac Ninh, Quang Ninh, Hai Duong, Hai Phong, Hung Yen, Nam Dinh, Ninh Binh, Cao Bang, Lao Cai, Yen Bai, Thai Nguyen, Lang Son, Bac Giang, Phu Tho, Son La, Hoa Binh, Thanh Hoa, Nghe An, Quang Tri, Thua Thien - Hue, Da Nang, Quang Nam, Quang Ngai, Binh Dinh, Phu Yen, Khanh Hoa, Binh Thuan and Lam Dong, over the period of $2005-2012$ via the estimation technique of difference panel GMM. 
The structure of the paper is as follows. Section 2 introduces the theoretical framework of the relationship between institutions and FDI inflows, followed by Section 3 reviewing the existing literature, which describes recent empirical research into the impact of institutional quality on FDI inflows. While methodology and data are presented in Section 4, Section 5 offers estimated results and discussion. The final section concludes and suggests policy implications.

\section{Theoretical framework}

The theoretical framework presented here is based on the arguments of Kang \& Jiang (2012).

Dunning $(1977,1993)$ developed the eclectic paradigm to explain FDI activities. Accordingly, advantages of ownership, location, and internalization determine FDI behavior of enterprises. However, FDI location choice of multinational companies may be partially explained by economic efficiency because FDI enterprises also need institutional legitimacy for their business activities in order to survive and succeed in a challenging and competing foreign environment (Kostova \& Zaheer, 1999). The primary criterion of choosing a location is the crucial difference between the eclectic paradigm and the institutional approach to the issue of FDI location choice. In fact, to the eclectic paradigm, economic efficiency is regarded as the ultimate determinant of location choice. From this perspective, multinational companies adopt the ability of institutions to lower the transaction costs associated with FDI that result from an uncertain environment (Hoskisson et al., 2000). On the other hand, to the institutional approach, institutional legitimacy is considered as the primary criterion. The core hypothesis of institutional theory is that the organizations embedded in must adapt to their institutional environment to obtain legitimacy (Zukin \& DiMaggio, 1990). Thus, multinational companies are motivated to become isomorphic with their environment in order to improve their legitimacy, although there is no evidence to confirm that such actions increase efficiency (Yiu \& Makino, 2002). It is even argued that the demand to incorporate institutional factors into FDI theory may hardly be over-emphasized (Sethi et al., 2002). For a lack of institutional content in the eclectic paradigm, Dunning (2006) indicated that institutional factors should importantly be integrated in an extension of the model. Dunning \& Lundan (2008) suggested that institutions have strong impact on all the three components of the paradigm. Therefore, integrating an 
institution-based view into FDI theory is virtually essential for the case of emerging countries as the FDI theory has been developed on the experience of multinational companies from Western countries, where fully developed market-based institutions enable background conditions for business activities, although these institutions are almost invisible. By contrast, Peng et al. (2008) demonstrated the absence of formal market-based institutions in emerging countries, and thus organizations are under constraint of institutional context, specified by highly visible state-interference.

\section{Literature review}

Most countries, especially developing ones, need FDI capital to promote the economic growth and improve people's income. However, whether FDI inflows to a host country is likely or not depends on the macroeconomic environment of that country. Recent literature reviews confirmed the role of institutional quality in establishing an appropriate macroeconomic environment to attract FDI inflows. Indeed, most empirical research has showed that the quality of institutions has strong impact on attracting the FDI inflows in host countries.

Anghel (2005) empirically examined the effects of institutional quality on attracting foreign direct investment. In an empirical analysis of cross-section data by applying estimation methods of ordinary least squares and instrumental variables, the author found that different aspects of the quality of institutions from a country (corruption, protection of property rights, and policies related to opening and maintaining a business, etc.) were almost always significant in attracting FDI.

The relationship between political risk, institutions, and foreign direct investment inflows was investigated by Busse and Hefeker (2007). Based on various econometric techniques (cross-section estimation, fixed effects, random effects, and GMM) for a data sample of 83 developing countries from 1984 to 2003, the estimated results confirmed several highly significant determinants of foreign investment inflows, namely government stability, absence of internal conflict and ethnic tensions, basic democratic rights, and ensured law and order.

Another empirical study by $\mathrm{Du}$ et al. (2008) examined the effects of economic institutions, including property rights protection and contract enforcement, on the location choice of foreign direct investment for 6288 US multinationals investing in various China's regions for the period of 1993-2001. Through the application of the 
discrete choice model and the conditional logit method, the estimated results showed that US multinationals prefer to invest in those regions that have better protection of intellectual property rights, lower degree of government intervention in business operations, lower level of government corruption, and better contract enforcement.

Do countries with stronger governing institutions and more business-friendly policies really attract more foreign direct investment? Wernick et al. (2009) sought to answer this question by investigating the effects of institutional quality on FDI for a sample of 64 emerging economies over the 1996-2006 period. As with multiple regression models, the results confirmed that the institutional quality had significantly positive impact on FDI in these countries.

According to Bissoon (2011), control of corruption, better rule of law, political stability, and better freedom of expression of the media were employed as indicators of good governance and institutional quality. The author's paper addressed the impact of institutional quality on FDI in 45 developing countries in the African, Latin American and Asian between 1996 and 2005. The results achieved from OLS estimation showed that the quality of some institutions in the host country had a significantly enormous influence on inward FDI. Although different indicators of institutional quality are complementary to each other, their combined effect has been found to reinforce the level of FDI inflows to the host country.

In order to pinpoint the determinants of FDI location choices of Chinese multinational companies, Kang and Jiang (2012) established a conceptual framework that combines traditional economic factors and institutional perspective. By using panel data of Chinese outward FDI to eight economies in East and Southeast Asia in period of 1996-2008 and estimation method of random effects, several hypotheses were developed in line with the framework and empirically tested. The estimated results confirmed that institutional variables demonstrated a higher level of significance, complexity, and diversity in determining FDI location choice in comparison with economic variables. However, both types of these were discovered to be major determinants of FDI location choice of Chinese multinational firms.

Jadhav (2012) studied the role of economic, institutional, and political factors in attracting foreign direct investment (FDI) in BRICS (Brazil, Russia, India, China, and South Africa) economy during the years 2000-2009. Applying multiple regression models allowed for results showing that besides economic and political factors, such 
institutions as rule of law and voice and accountability had statistically significant effects on FDI.

Based on a panel data analysis of 164 countries from 1996 to 2006 and OLS estimation along the instrumental variable and fixed effects, random effects, Buchanan et al. (2012) investigated the impact of institutional quality on FDI levels and volatility. Their results implied that institutional quality had positive and significant effects on FDI. In addition, ceteris paribus, institutional quality was significantly negatively connected with FDI volatility, which may have had an adverse impact on economic growth in accordance with Lensink and Morrisey (2006). Accordingly, these authors note that policies of attracting FDI into countries by providing the "correct" macroeconomic environment would be ineffective without an equal emphasis on institutional reform.

Mina (2012) empirically tested the theoretical debate on the adoption of the best approach to the problems of institutional reforms, having been identified by Rodrik (2008), in the context of property rights protection and FDI flows to eight MENA countries in the period of 1990-2008. The first best approach consisted of reinforcing domestic institutional functions only, while the second one comprised, in addition, enforcing bilateral investment treaties and the interaction between functions and treaties. With estimation techniques of random/fixed effects and GMM, the estimated results showed that both approaches to decreasing investment expropriation risk encouraged FDI flows. Moreover, the author also established that the positive effect of the second best approach was conditional upon success of the first one, suggesting that the two approaches be complementary.

Through models of gravity equation and a novel dataset of bilateral FDI flows of 82 host countries and 163 source countries in the period of 1996-2007, Aleksynska \& Havrylchyk (2013) analyzed location choices of investors from emerging economies with an emphasis on institutions and natural resources. The results confirmed that FDI flows from the South had a more regional aspect than investment from the North. Asymmetric effects of institutional distance on FDI flows depend on whether investors choose countries with better or worse institutions. In countries with worse ones, large institutional distance reduces FDI inflows, but this impact is diminished for destination countries with substantial resources. 
Combining the traditional factors with institutional variables over the 1996-2009 period and using panel OLS and fixed effects methods (selected via the Hausman test), Tintin (2013) discussed the determinants of FDI inflows in six Central and Eastern European countries (CEEC). The paper identified whether and how these factors differed across four investor countries (EU-15, the US, China, and Japan). Besides the significantly positive role of GDP size, trade openness, and EU membership, results verified that institutions (measured by economic freedoms, state fragility, political rights, and civil liberties indices) had economically positive effects on FDI inflows.

Using panel data from 287 Chinese cities over the period of 1999-2005 and employing two-way fixed effects models to control for year- and city-specific effects, Wang et al. (2013) found that the host city's institutional development promoted the positive effects of FDI and lowers its negative ones. Interestingly, compared with nonethnic-linked FDI, the moderating effect of ethnic-linked FDI was smaller. In an attempt to unravel the role of institutional development in moderating the ambiguous effects of FDI, this research confirmed that a host's ability to receive the advantages of FDI while reducing its associated costs was both plausible and pivotal.

Kuzmina et al. (2014) scrutinized the impact of governance quality on FDI in Russia. Using a businesses survey across 40 administrative districts and estimation techniques of one- and two-stage instrumental variable, they found that higher frequency of illegal payments and higher pressure from regulatory agencies, enforcement authorities, and criminals had significantly negative effects on FDI. In addition, it has been demonstrated that the moving of governance quality from the average to the top across Russian regions more than doubles the FDI stock.

\section{Methodology and data}

\subsection{Methodology}

This paper aims to investigate the effects of institutional quality on attracting FDI inflows in a sample of panel data for 43 provinces over the period of 2005-2012. Thus, the empirical equation is as follows:

$Y_{i t}=\alpha_{i t}+\beta_{1} X_{i t}+\beta_{2} Z_{i t}+\eta_{i}+\xi_{i t} ; i=1,2,3, \ldots, N ; t=1,2,3, \ldots, T$

where $\eta_{i} \sim \operatorname{iid}\left(0, \sigma_{\eta}\right) ; \zeta_{i t} \sim \operatorname{iid}\left(0, \sigma_{t}\right) ; E\left(\eta_{i} \zeta_{i t}\right)=0 ; Y_{i t}$ is the FDI accumulation capital; $X_{i t}$ is the institutional quality (Provincial Competitiveness Index-PCI) while $Z_{i t}$ is a 
set of control variables; $\eta_{i}$ is an unobserved time-invariant, country-specific effect; and $\zeta_{i t}$ is an observation-specific error term.

Lags of the regressand have certain impact on it. Thus, the first lag of the dependent variable is added in the model. Subtracting $Y_{i t-1}$ for both sides of Eq. 1, we subsequently have the resulting equation:

$$
Y_{i t}-Y_{i t-1}=\alpha_{i t}+\beta_{0} Y_{i t-1}+\beta_{1} X_{i t}+\beta_{2} Z_{i t}+\eta_{i}+\xi_{i t}
$$

Eq. 2 is a dynamic model. $d Y=Y_{i t}-Y_{i t-1}$ is the first difference of $Y$, a proxy for growth rate of FDI capital. $Y_{i t-1}$ on the right side of Eq. 2 is a proxy for initial level of FDI capital.

The set of variables $Z_{i t}$ includes some of the following determinants, which have impact on attracting FDI inflows: real GDP per capita (in logarithm form), labor force, development gap, trade openness, and infrastructure.

The dynamic characteristics in Eq. 2 show that the country-specific fixed effects can be correlated with the lagged dependent variable, and some explanatory variables may be endogenous. It may also cause OLS inconsistency and bias the estimates. However, the difference panel Generalized Method of Moments (GMM) estimator, developed by Arellano and Bover (1995), and Blundell and Bond (1998), properly tackles these problems. It utilizes the lagged differences of the predetermined variable as instruments for their levels and the differences of the strictly exogenous variables (as in the standard IV procedure). Not only does the dynamic panel GMM estimation use the appropriate lags of the instrumented variables to generate internal instruments but it also employs the pooled dimension of the panel data, thereby not imposing restrictions upon the length of each individual time dimension in the panel. This enables the use of a suitable lag structure to exploit the dynamic specification of the data.

\subsection{Data}

Cross-sections and time series are extracted to accommodate the panel data of 43 provinces over period of 2005-2012 from General Statistics Office of Vietnam (GSO). There are 20 out of 63 provinces excluded due to the unavailability of data. The variables are accordingly defined and calculated as follows:

- Foreign direct investment capital (FDI): FDI accumulation capital in a yearly basis for each province, defined as a share of GDP of each province. It means that every year 
in each province some FDI capital stock flows in, and some other FDI capital stock flows out. Accordingly, the final FDI capital stock every year in each province may increase or decrease, depending on such inward FDI capital and outward FDI capital.

- Provincial competitiveness index (lnPCI): Data on the institutional quality are obtained from the Vietnam Provincial Competitiveness Index survey, which has been jointly carried out by United States Agency for International Development and the Vietnam Chamber of Commerce and Industry for the Vietnam Competitiveness Initiative in an effort to assess and rank provincial governments by their regulatory environments for private sector development. The PCI index is commonly used in many studies on provincial governance in Vietnam such as Malesky and Taussig (2009), Malesky (2008), Tran et al. (2008), Vu et al. (2007), Nguyen and Dijk (2012), and Dang (2013), being in form of natural logarithm.

- Real GDP per capita (lnGDP): As a real gross domestic product of a province and a proxy for its market size, this has often been employed as a control variable in various studies related to FDI inflows (Anghel, 2005; Wernick et al., 2009; Bissoon, 2011; Kang \& Jiang, 2012; Buchanan et al., 2012; Tintin, 2013, Wang et al., 2013; Dang, 2013; Kuzmina et al., 2014). The variable is also used in form of natural logarithm.

- Labor force (LABO): a ratio of working age population (those aged 15 to 64) to the total population of a province; this variable is considered one of the advantages of a host country to attract the FDI inflows (Mina, 2012; Wang et al., 2013).

- Development gap (GAP): a difference between real GDP per capita of a province and the average of real GDP per capita of 43 provinces; this variable is a proxy for level of provincial development. Based on Li and Liu (2005) and Krogstrup \& Matar (2005), GAP of a province $i$ at time $t$ is defined as follows:

$$
G A P_{i t}=100 \% \frac{G D P_{i t}-\overline{G D P_{t}}}{\overline{G D P_{t}}}
$$

where $G D P_{i t}$ is gross domestic product of a province $i$ at time $t$ and $\overline{G D P_{t}}$ is the average GDP of 43 provinces at time $t$.

Trade openness (OPEN): a ratio between sum of exports and imports and GDP, which is proxy for the policy of openness of a country; trade openness has been used in multiple studies at the level of countries (Anghel, 2005; Wernick et al., 2009; Bissoon, 2011; Kang \& Jiang, 2012; Buchanan et al., 2012; Mina, 2012, Tintin, 2013). At the 
level of provinces, Thanh and Tien (2014) applied this variable to the relationship between FDI and economic growth.

Infrastructure (lnTELE): The infrastructure may be measured in some ways such as the length of highway in one kilomter square (Du et al., 2008), the length of railway (Kuzmina et al., 2014), or the number of telephone lines per 100 people (Bissoon, 2011). In this study it is the number of telephone lines per 100 people. Being a proxy for development of infrastructure in a province, it is used in form of natural logarithm.

The statistical description of all data from General Statistics Office of Vietnam (GSO) is presented in the Table 1.

\section{Table 1}

Statistical description

\begin{tabular}{lccccc}
\hline Variable & Obs. & Mean & Std. Dev. & Min & Max \\
\hline Foreign direct investment (FDI) & 334 & 5.589732 & 7.016382 & .0002343 & 48.46297 \\
$\begin{array}{l}\text { Provincial competitiveness index } \\
\text { (lnPCI) }\end{array}$ & 334 & 405.2275 & 11.34745 & 369.3276 & 434.6362 \\
Real GDP per capita (lnGDP) & 334 & 168.4566 & 55.01901 & 74.97094 & 406.8367 \\
Labor force (LABO) & 334 & 55.01675 & 5.230292 & 36.62162 & 67.6647 \\
Development gap (GAP) & 334 & 3.413696 & 117.1815 & -62.1681 & 945.0399 \\
Trade openness (OPEN) & 334 & 99.58758 & 130.5953 & 2.364154 & 749.1873 \\
Infrastructure (lnTELE) & 334 & 540.5644 & 72.65276 & 351.7498 & 782.2725 \\
\hline
\end{tabular}

The matrix of correlation coefficients for the variables is given in Table 2. All of the correlation coefficients between independent variables and the dependent one are statistically significant at the lowest level of 5\%. Accordingly, all the independent variables have positive impact on attracting FDI flows, which means that reforming and improving the institutional quality play an important role in attracting FDI flows, and such other factors as economic growth (market size), labor force, development level, trade openness, and infrastructure also have significant effects on attracting this kind of capital flows. 


\section{Table 2}

Matrix of correlation coefficients

\begin{tabular}{llllllll}
\hline & FDI & $\ln P C I$ & $\operatorname{lnGDP}$ & LABO & GAP & OPEN & $\ln$ TELE \\
\hline FDI & 1.0000 & & & & & \\
$\ln P C I$ & $0.3420^{* * *}$ & 1.0000 & & & & \\
$\operatorname{lnGDP}$ & $0.2887^{* * *}$ & $0.3821^{* * *}$ & 1.0000 & & & \\
LABO & $0.1531^{* * *}$ & -0.0804 & $-0.3060^{* * *}$ & 1.0000 & & \\
GAP & $0.1333^{* *}$ & $0.1914^{* * *}$ & $0.8247^{* * *}$ & $-0.4281^{* * *}$ & 1.0000 & & \\
OPEN & $0.7576^{* * *}$ & $0.3677^{* * *}$ & $0.3885^{* * *}$ & 0.0868 & $0.1912^{* * *}$ & 1.0000 & \\
$\operatorname{lnTELE}$ & $0.2480^{* * *}$ & $0.1649^{* * *}$ & $0.4776^{* * *}$ & -0.0792 & $0.2182^{* * *}$ & $0.3360^{* * *}$ & 1.0000 \\
\hline
\end{tabular}

Note: ${ }^{* *}$ and ${ }^{* * *}$ denote significance at $5 \%$ and $1 \%$ level, respectively.

\section{Results and discussion}

The estimated results derived from panel differenced GMM Arellano-Bond method is shown in Table 3. Signs of the estimated coefficients, which indicate effects of economic growth and trade openness on attracting FDI flows, are opposite to those of the correlation coefficients given in Table 2. It implies that there exists an endogenous phenomenon between the regressand and regressors. Therefore, the panel differenced GMM Arellano - Bond estimation with instrumental variables seems to be appropriate for this empirical model.

To assess the validity of instruments in GMM first-difference estimation and the serial auto-correlation of residuals, the study performs the Sargan test (test of overidentifying restrictions with the null hypothesis that "the instruments as a group are exogenous") as well as the Arellano - Bond test for serial correlation (AR[2]), which is applied to the differenced residuals to purge the unobserved and perfectly autocorrelated. The results of these tests show that all null hypothesizes are rejected. Thus, the instruments are appropriate, and there is no phenomenon of serial correlation for residuals in second differences. 
of FDI capital in the previous year has significantly negative impact on that in the current one.

The recent literature indicated that market size (real GDP per capita) had positive effects on attracting FDI capital flows (Anghel, 2005; Bissoon, 2011; Buchanan et al., 2012; Tintin, 2013; Kuzmina et al., 2014) because FDI enterprises may produce goods and services to satisfy domestic needs. In the case of provinces in Vietnam, in fact, the reverse applies, and it is similar to that having been indicated by Wernick et al. (2009) and Wang et al. (2013). As far as this study is concerned, rich provinces (high real GDP per capita) may have enough capital investment to meet requirements of economic growth, so these are not willing to carry out necessary reforms in order to attract the FDI capital. In addition, in Vietnam most of FDI enterprises' goods and services are encouraged to export to worldwide markets, which means that local people's income is insignificant to their investment decisions. Thus, it is signified by the case of Vietnam's provinces that the market size (real GDP per capita) has a negative impact on attracting FDI capital.

Labor force of a country is an advantage of attracting FDI capital. Wang et al. (2013) suggest that it has a significantly positive impact on attracting the inflows. Similarly, availability of the labor force in a province brings foreign investors two of the following benefits: (i) adequate supply of labor force facilitates smooth operations of FDI enterprises, and (ii) it reduces costs of salary paid to workers. In addition to preferential treatments of provinces, FDI enterprises may regard the local labor force as one of the important factors for their investment decisions. Thus, this factor has a positive impact on attracting FDI inflows.

The development level of a country/region is also one of the important factors to attract more FDI inflows. Many foreign companies of high technology that have been investing in provinces desire to receive high skilled workers in local areas, and these workers will in turn acquire modern technologies from foreign countries. It implies that a province with a higher level of development will attract more FDI capital from high technology enterprises. Therefore, the development level impact on FDI capital is also positive.

Infrastructure is a factor which is considered both a challenge and a chance for foreign investors. Kirkpatrick et al. (2006) and Pham (2008) indicated that countries with bad infrastructure would attract infrastructure investors to build, develop, and 
improve in the relevant sector. However, other foreign investors are also interested in the domain. Bad infrastructure will make the operations of foreign enterprises more difficult, increase costs, and even burden them with tougher competitions with other enterprises in global markets. Thus, improving infrastructure is one of the priorities of provinces in their attracting FDI inflows. The estimated results, accordingly, show that provinces with better infrastructure will attract more FDI capital, consistent with Du et al. (2008), Bissoon (2011), and Kuzmina et al. (2014).

Similar to the total sample of all provinces in Vietnam, to assess and compare effects of institutional quality on attracting FDI inflows at the regional level, the study continues to employ difference panel GMM Arellano-Bond estimation for the three regions: Northern region (18 provinces), Central region (12 provinces), and Southern region (13 provinces). The estimated results for these three regions are presented in Table 4,5 , and 6 .

\section{Table 4}

Differenced panel GMM Arellano-Bond estimations for 18 provinces at the Northern area Dependent variable: Foreign direct investment

\begin{tabular}{lccc}
\hline & Coeff. & Std. & Prob. \\
\hline Foreign direct investment (-1) & $-.8159939^{* * *}$ & .1562194 & 0.000 \\
Provincial competitiveness index & $0.1759181^{*}$ & .1018363 & 0.088 \\
Real GDP per capita & 0.0206332 & .0572211 & 0.719 \\
Labor force & .2744998 & .4337754 & 0.529 \\
Development gap & -0.119211 & .084035 & 0.160 \\
Trade openness & -0.0080826 & .0109667 & 0.463 \\
Infrastructure & -0.0250499 & .0183791 & 0.177 \\
\hline Obs & & 81 & \\
\hline Sargan test & & 0.783 & \\
\hline AR(2) test & & 0.100 & \\
\hline
\end{tabular}

Note: ${ }^{* * *}$ and ${ }^{*}$ denote significance at $1 \%$ and $10 \%$ level, respectively. 


\section{Table 5}

Differenced panel GMM Arellano-Bond estimations for 12 provinces at the Central area

Dependent variable: Foreign direct investment

\begin{tabular}{llll}
\hline & Coeff. & Std. & Prob. \\
\hline Foreign direct investment (-1) & $-1.040158^{* * *}$ & .1480169 & 0.000 \\
Provincial competitiveness index & 0.0566839 & .0773477 & 0.466 \\
Real GDP per capita & -0.0435278 & .091754 & 0.637 \\
Labor force & 0.0839089 & .361434 & 0.817 \\
Development gap & -0.0990669 & .1405901 & 0.484 \\
Trade openness & -0.0032001 & .013958 & 0.819 \\
Infrastructure & $0.0655892^{* * *}$ & .0221133 & 0.004 \\
\hline Obs & 71 & & \\
\hline Sargan test & 0.295 & & \\
\hline AR(2) test & 0.209 & & \\
\hline
\end{tabular}

Note: ${ }^{* * *}$ denotes significance at $1 \%$ level.

\section{Table 6}

Differenced panel GMM Arellano-Bond estimations for 13 provinces at the Southern area

Dependent variable: Foreign direct investment

\begin{tabular}{llll}
\hline & Coeff. & Std. & Prob. \\
\hline Foreign direct investment $(-1)$ & $-.5135006^{* * *}$ & .1654469 & 0.003 \\
Provincial competitiveness index & $.2347043^{* *}$ & .1028488 & 0.025 \\
Real GDP per capita & -0.0426884 & .7698176 & 0.956 \\
Labor force & 0.06119 & .0667338 & 0.362 \\
Development gap & -0.0035577 & .0955116 & 0.970 \\
Trade openness & $0.0345303^{*}$ & .0181437 & 0.061 \\
Infrastructure & 0.0032636 & .030953 & 0.916 \\
\hline Obs & 78 & & \\
\hline
\end{tabular}


Dependent variable: Foreign direct investment

\begin{tabular}{|c|c|c|c|}
\hline & Coeff. & Std. & Prob. \\
\hline Sargan test & 0.128 & & \\
\hline $\mathrm{AR}(2)$ test & 0.183 & & \\
\hline
\end{tabular}

According to Table 4, 5, and 6, the estimated results show: (i) First lag of FDI capital has a negative impact on attracting FDI inflows in all three regions; (ii) The impact of institutional quality on attracting FDI inflows is statistically significantly positive in Northern and Southern regions but not in Central region; and (iii) In the Central region infrastructure helps attract FDI inflows while in the Southern region trade openness increases more FDI capital.

Indeed, the first lag of FDI capital has a negative impact on attracting FDI inflows in all the three regions, which is consistent with that of the total sample of all provinces. However, unlike those in the total sample of all provinces and the subsample of Northern and Southern regions, the impact of institutional quality on attracting FDI inflows is not insignificant in the Central region. It shows that in most of the Central provinces reforms of administrative formalities are not well conducted, and incentive policies for foreign investors are not attractive. Contrarily, due to difficult socioeconomic conditions in Central region, the central government priorly finances and improves infrastructure in these provinces to enhance the living standards of local people. This was shown in Resolution No. 26-NQ/TW (issued on 5/8/2008) and Decision No. 850/TTg-QHQT (June 17, 2013) on "Infrastructure Development Project for 13 Central Provinces" sponsored by Asia Development Bank and Economic Forum in Central Areas (held on August 15, 2014), and has thus become competitive advantages for these provinces in their attracting FDI inflows.

Similar to the total sample of all provinces, in Southern region the trade openness has positive effects on attracting FDI inflows. Compared with others, provinces of the Southern region are recognized to integrate highly into worldwide markets. In these provinces local governments usually adjust and promulgate appropriate policies on accelerating incentives to encourage business transactions with other countries. It is obviously of great importance that FDI inflows be attracted as the export of goods and services is a major priority of foreign enterprises. 


\section{Conclusions and policy implications}

This paper has empirically investigated the effects of institutional quality on attracting FDI inflows with control variables such as real GDP per capita, labor force, development gap, trade openness, and infrastructure and via difference panel GMM estimation technique. The study is carried out for a sample of 43 provinces of Vietnam over the period of 2005-2012.

In the total sample the estimated results show that the institutional quality has significantly positive impact on attracting FDI inflows. Although the institutional quality is measured in some different ways, most studies (Wernick et al., 2009; Kang \& Jiang, 2012; Buchanan et al., 2012; Wang et al., 2013; Kuzmina et al., 2014, etc.) confirm the positive effects of institutions on attracting the FDI inflows. Except for trade openness, all the remaining control variables such as first lag of FDI inflows, economic growth, labor force, development level, and infrastructure also play a significant role in attracting FDI inflows. However, in the sub-sample of regions, the results indicate that the effects of quality of institutions in the Northern and Southern regions on attracting FDI inflows are statistically significantly positive. In addition, infrastructure in Central region and trade openness in Southern one are more than important determinants of attracting FDI inflows in these areas.

From the policy perspective, local governments in these provinces should carry out the following in order to attract more FDI capital from foreign enterprises:

(i) Improving the institutional quality: Provinces should

- continuously reform administrative formalities, for example, put the model of egovernment into practice, and especially monitor and evaluate the work attitude behavior of such provinces' staff;

- investigate and learn from other neighbor countries the policies on tax incentives to attract more high technology-FDI inflows;

- establish departments to support legal procedures for foreign investors;

- be willing to acquire foreign investors' ideas and support them with solutions to major disturbance from regular operations;

- consult economic experts before promulgating regulations; 
- publicly introduce and supply guidelines, policies, administrative formalities, and preferential treatments to provinces via communication occurring through mass media such as newspapers, radio, television, etc.; and

- periodically host economic forums to collect foreign investors' ideas and economic experts' policy implications about how to effectively attract FDI inflows.

(ii) Enhancing knowledge and skills for local labor force: Provinces should encourage FDI enterprises to actively provide their trainings by tax reduction and preferential loans from banks and so forth.

(iii) Developing and improving the quality of infrastructure: Provinces should create particular incentives for enterprises (domestic and foreign ones), those investing in improving infrastructure by special legal procedures, long operation times, preferential loans from banks, etc.

\section{Shortcomings of the study:}

(i) Data on GDP per capita in provinces may not be highly accurate due to the inappropriate calculation methods for provinces.

(ii) Provincial competitiveness index (PCI): As aforementioned, PCI has been employed by some studies as a proxy for the institutional quality in Vietnam. However, so far nobody clearly defines its nature.

Therefore, further research in the future (if any) should pay more attention to these two discussed limitations

\section{References}

Aleksynska, M., \& Havrylchyk, O. (2013). FDI from the South: The role of institutional distance and natural resources. European Journal of Political Economy, 29, 38-53.

Anghel, B. (2005). Do institutions affect foreign direct investment? International Doctorate in Economic Analysis, 2-40.

Bissoon, O. (2011). Can better institutions attract more foreign direct investment (FDI)? Evidence from developing countries. International Conference on Applied Economics, 59-70.

Buchanan, B. G., Le, Q. V., \& Rishi, M. (2012). Foreign direct investment and institutional quality: Some empirical evidence. International Review of Financial Analysis, 21, 81-89.

Busse, M., \& Hefeker, C. (2007). Political risk, institutions and foreign direct investment. European Journal of Political Economy, 23, 397-415. 
Dang, D. A. (2013). How foreign direct investment promote institutional quality: Evidence from Vietnam. Journal of Comparative Economics, 41(4), 1054-1072.

Du, J., Lu, Y., \& Tao, Z. (2008). Economic institutions and FDI location choice: Evidence from US multinationals in China. Journal of Comparative Economics, 36, 412-429.

Dunning, J. H. (1977). Trade, location of economic activity and the MNE: A search for an eclectic approach. In B. Ohlin, P. Hesselborn \& M. Wijkman (eds.), The international allocation of economic activity (pp. 395-418). New York: Holmes and Meier.

Dunning, J. H. (1993). Multinational enterprises and the global economy. U.K.: Addison-Wesley, Workingham.

Dunning, J. H. (2006). Comments on dragon multinationals: New players in $21^{\text {st }}$ century globalization. Asian Pacific Journal of Management, 23, 139-141.

Dunning, J. H., \& Lundan, S. (2008). Institutions and the OLI paradigm of the multinational enterprise. Asia Pacific Journal of Management, 25, 573-593.

Hoskisson, R., Eden, L., Lau, C. M., \& Wright, M. (2000). Strategies in emerging economies. Academy of Management Journal, 43, 249-269.

Jadhav, P. (2012). Determinants of foreign direct investment in BRICS economies: Analysis of economic, institutional, and political factor. Procedia-Social and Behavioral Sciences, 37, 5-14.

Kang, Y., \& Jiang, F. (2012). FDI location choice of Chinese multinationals in East and Southeast Asia: Traditional economic factors and institutional perspective. Journal of World Business, 47, $45-53$.

Kostova, T., \& Zaheer, S. (1999). Organisational legitimacy under conditions of complexity: The case of the multinational enterprise. Academy of Management Review, 24, 64-81.

Kuzmina, O., Volchkova, N., \& Zueva, T. (2014). Foreign direct investment and governance quality in Russia. Journal of Comparative Economics, 42(4), 874-891.

Malesky, E. J. (2008). Straight ahead on red: How direct investment empowers sub-national leaders. Journal of Politics, 70(1), 97-119.

Malesky, E. J., Taussig, M. D. (2009). Out of gray: The impact of provincial institutions on business formalization in Vietnam. Journal of East Asian Studies, 9(2), 249-290.

Mina, W. M. (2012). The institutional reforms debate and FDI flows to the MENA region: The "best" ensemble. World Development, 40, 1798-1809.

Nguyen, T. T., Dijk, M. A. van (2012). Corruption, growth, and governance: Private vs. state owned firms in Vietnam. Journal of Banking and Finance, 36(11), 2935-2948.

Peng, M. W., Wang, D. Y. L., \& Jiang, Y. (2008). An institution-based view of international business strategy: A focus on emerging economies. Journal of International Business Studies, 39, 920-936. 
Sethi, D., Guisinger, S., Ford, D. L., \& Phelan, S. E. (2002). Seeking greener pastures: A theoretical and empirical investigation into the changing trend of foreign direct investment flows in response to institutional and strategic factors. International Business Review, 11, 685-705.

Stoian, C. (2013). Extending Dunning's investment development path: The role of home country institutional determinants in explaining outward foreign direct investment. International Business Review, 22, 615-637.

Tintin, C. (2013). The determinants of foreign direct investment inflows in the Central and Eastern European Countries: The importance of institutions. Communist and Post-Communist Studies, 46, 287-298.

Tran, B. T., Grafton, Q. R., \& Kompas, T. (2008). Institutions matter: The case of Vietnam. Journal of Socio-Economics, 38, 1-12.

Vu, T. A. T., Le, T. V., \& Vo, T. T. (2007). Provincial extralegal investment incentives in the context of decentralisation in Vietnam: Mutually beneficial or a race to the bottom? United Nations Development Program Vietnam Working Paper Series, Hanoi, Vietnam.

Wang, D. T., Gu, F. F., Tse, D. K., \& Yim, C. K. B. (2013). When does FDI matter? The roles of local institutions and ethnic origins of FDI. International Business Review, 22, 450-465.

Wernick, D. A., Haar, J., \& Singh, S. (2009). Do governing institutions affect foreign direct investment inflows? New evidence from emerging economies. International Journal of Economics and Business Research, 1, 317-332.

Zukin, S., \& DiMaggio, P. (1990). Structures of capital: The social organization of the economy. Cambridge: Cambridge University Press. 